\title{
Oxidative Stress Induced by a Dihydropyrazine Derivative
}

\author{
Shinji TAKechi, ${ }^{*, a}$ Kazuhide NAKahara, ${ }^{a}$ Masaru Adachi, ${ }^{b}$ and Tadatoshi Yamaguchi ${ }^{a}$ \\ ${ }^{a}$ Faculty of Pharmaceutical Sciences, Sojo University; Ikeda 4-22-1, Kumamoto 860-0082, Japan: and ${ }^{b}$ Laboratory of \\ Postharvest Biology and Technology, Faculty of Agriculture, University of Miyazaki; 1-1 Gakuen Kibanadai-nishi, \\ Miyazaki 889-2192, Japan.
}

Received September 8, 2008; accepted November 27, 2008; published online November 28, 2008

The Maillard reaction contributes to the complications of diabetes and normal aging. Dihydropyrazines (DHPs), which are produced during the Maillard reaction, generate radicals and possess DNA strand-cleaving activities in vitro. In the present study, we evaluated the genotoxic and cytotoxic potentials of a DHP derivative, cyclohexyl-DHP, which is obtained as a mixture of two isomers, 2,3,5,6,7,8-hexahydroquinoxaline (endo-type) and 1,2,3,5,6,7-hexahydroquinoxaline (exo-type), fused with a cyclohexyl ring. Cyclohexyl-DHP caused DNA strand breaks in plasmid pUC18, especially in the presence of $\mathrm{Cu}^{2+}$. By using Escherichia coli mutant strains, we observed that cyclohexyl-DHP exposure strongly reduced the survival rate of a cytosolic sodium dodecyl sulfate (SOD)-deficient strain ( $\operatorname{sod} A \operatorname{sodB})$, significantly reduced the survival rates of DNA repair-deficient $\operatorname{strains}(\operatorname{rec} A$ and $u v r B$ ) and mildly reduced the survival rate of a catalase-deficient strain (katE katG) compared with the survival rate of the wild-type strain. Addition of $\mathrm{Cu}^{2+}$ enhanced the cell killing ability of cyclohexyl-DHP. The frequency of mutations induced by cyclohexyl-DHP increased dose-dependently in the sodA sodB strain. Assays with the highly water-soluble tetrazolium salt WST-1 revealed that cyclohexyl-DHP strongly generated superoxide anions. Moreover, cyclohexyl-DHP elevated the protein carbonyl levels in $E$. coli. These findings indicate that cyclohexyl-DHP could potentially generate superoxide anions, and cause not only breakage of chromosomal DNA leading to mutagenic lesions but also induce damage to cellular proteins.

Key words dihydropyrazine; Escherichia coli; DNA damage; mutagenicity; superoxide anion; protein oxidation

The Maillard reaction, which comprises a non-enzymatic reaction between reducing sugars and amino acids, produces hundreds of highly reactive compounds. Dihydropyrazine (DHP) is produced by condensation of 2 mol of D-glucosamine, ${ }^{1)}$ and some DHP derivatives generate various radical species that cause DNA strand cleavage in vitro. ${ }^{2)}$ Since many pyrazine derivatives have been detected in various foods ${ }^{3)}$ and human urine, ${ }^{4)}$ we speculated that DHPs, which are presumed to be precursors of pyrazines, would be responsible for certain diseases. However, there are few reports regarding the biological and physiological roles of DHPs.

In a previous paper, we reported that methyl-substituted dihydropyrazines (Me-DHPs), such as 2,3-dihydro-5,6-dimethylpyrazine, had DNA strand-breaking activity, inhibited growth and induced mutagenesis in Escherichia coli. ${ }^{5)} \mathrm{Al}-$ though phenyl-substituted dihydropyrazines (Ph-DHPs) have much higher DNA strand-breaking activities and produce higher levels of radical species than Me-DHPs, ${ }^{6,7)}$ DNA repair-deficient bacteria were less sensitive to $\mathrm{Ph}-\mathrm{DHPs}$ than to Me-DHPs. ${ }^{8)}$ Recently, cyclohexyl-DHP, which was designed according to our hypothesis of a relationship between the chemical structures of DHP derivatives and DNA strandbreaking activities, ${ }^{9}$ ) was shown to possess a stronger DNA strand-breaking activity than Me-DHPs and Ph-DHPs. ${ }^{10}$ )

In the present study, we examined the cellular effects of a novel cyclohexyl-DHP with a cyclohexyl ring fused to the DHP. We found that it could strongly generate superoxide anions, and cause not only breakage of chromosomal DNA leading to mutagenic lesions but also induce oxidative damage to cellular proteins.

\section{MATERIALS AND METHODS}

Synthesis of DHPs A mixture of two isomers of cyclohexyl-DHP (Fig. 1), namely 2,3,5,6,7,8-hexahydroquinoxa- line (endo-type) and 1,2,3,5,6,7-hexahydroquinoxaline (exotype), was prepared using a previously described method. ${ }^{2)}$

Bacterial Strains The E. coli $\mathrm{K}-12$ strains used were all derived from AB1157 [ara-14 argE3 galK2 his-4 lacY1 leuB6 mtl-1 proA2 rpsL31 supE44 thi-1 thr-1 tsx-33 xyl-5]. ${ }^{11}$ $\mathrm{AB} 1157, \mathrm{AB} 2463$ [AB1157 recA] ${ }^{12)}$ and AB1885 [AB1157 $u v r B]^{11)}$ were obtained from the National BioResource Project (NIG, Japan). CATD [AB1157 katE katG] and SODD [AB1157 $\operatorname{sodA} \operatorname{sodB}]$ were described in a previous paper. ${ }^{8)}$

DNA Strand-Breaking Assay Reaction mixtures $(20 \mu \mathrm{l})$ containing $1 \mu \mathrm{g}$ of plasmid pUC18 were incubated with DHP in the presence or absence of $1 \mathrm{mM} \mathrm{CuCl}$, for $1 \mathrm{~h}$ at $37^{\circ} \mathrm{C}$. The resulting mixtures were analyzed by $0.8 \%$ agarose gel electrophoresis and stained with $0.5 \mu \mathrm{g} / \mathrm{ml}$ ethidium bromide. The DNA bands were visualized with an Epi-LightUV FA500 (Taitec, Japan).

Survival Assay Overnight cultures of E. coli were diluted by 100 -fold with fresh LB medium and grown at $37^{\circ} \mathrm{C}$ until the $\mathrm{OD}_{600}$ was approximately 0.1 . Approximately $1 \times 10^{8}$ bacteria were then challenged with DHP in the presence or absence of $1 \mathrm{mM} \mathrm{CuCl}_{2}$ for $1 \mathrm{~h}$ with shaking at $37^{\circ} \mathrm{C}$, plated on LB plates after serial dilutions in M9 salts and incubated overnight at $37^{\circ} \mathrm{C}$. The survival rates were calculated as the percentages of cells surviving after challenge with DHP. All experiments were conducted at least four times.

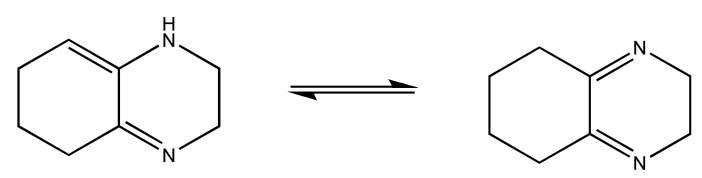

cyclohexyl-DHP : the mixture of 1,2,3,5,6,7-hexahydroquinoxaline (exo-type) and 2,3,5,6,7,8-hexahydroquinoxaline (endo-type)

Fig. 1. Chemical Structures of the DHP Isomers Employed in This Study 
Mutagenesis Assay Overnight cultures of E. coli were diluted by 100 -fold with fresh LB medium and grown at $37^{\circ} \mathrm{C}$ until the $\mathrm{OD}_{600}$ reached approximately 0.1 . The cells were then challenged with DHP and incubated with shaking for $1 \mathrm{~h}$ at $37^{\circ} \mathrm{C}$. After the DHP exposure, the samples were washed twice in M9 salts. The numbers of rifampicin-resistant mutant cells were measured after plating on LB agar containing rifampicin $(100 \mu \mathrm{g} / \mathrm{ml})$ and incubation overnight at $37^{\circ} \mathrm{C}$. The total numbers of cells were measured after plating on LB agar and incubation overnight at $37^{\circ} \mathrm{C}$. All experiments were conducted at least four times.

WST-1 Assay The WST-1 assay was carried out in 100 $\mu l$ of $50 \mathrm{~mm}$ phosphate buffer $(\mathrm{pH} 7.5)$ containing $2 \mathrm{~mm}$ WST-1 (4-[3-(4-iodophenyl)-2-(4-nitrophenyl)-2H-5-tetrazolio]-1,3-benzene disulfonate sodium salt) and various concentrations of DHP. Superoxide anion production was monitored by measuring the absorbance at $438 \mathrm{~nm}$. WST- 1 was purchased from Dojin Laboratories Co. (Japan).

Analysis of Protein Carbonyl Levels E. coli were challenged with DHP and incubated with shaking for $1 \mathrm{~h}$ at $37^{\circ} \mathrm{C}$. The cells were harvested and resuspended in $50 \mathrm{~mm}$ potassium phosphate buffer $(\mathrm{pH} 7.5)$ containing $2 \%$ 2-mercaptoethanol. 2,4-Dinitrophenylhydrazine (DNPH) derivatization and immunodetection of DNP-derivatized proteins were carried out using an OxyBlot Protein Oxidation Detection Kit (Chemicon International, U.S.A.).

\section{RESULTS}

DNA Strand Breakage by Cyclohexyl-DHP We previously reported that some DHP derivatives had DNA strandbreaking activity, and that cyclohexyl-DHP also appeared to possess DNA strand-breaking activity. To further examine whether cyclohexyl-DHP causes DNA damage, we exposed the double-stranded plasmid pUC18 to cyclohexyl-DHP. As shown in Fig. 2, the amount of covalently closed circular (CCC) DNA was slightly decreased by cyclohexyl-DHP. The loss of CCC-DNA induced by cyclohexyl-DHP was remarkably stimulated by the addition of $1 \mathrm{mM} \mathrm{CuCl}_{2}$.

Lethal Effects of Cyclohexyl-DHP on $E$. coli Strains To investigate the toxicity of cyclohexyl-DHP, we compared its effects on the survival rates of five strains of $E$. coli with an isogenic background (wild-type, $\operatorname{rec} A, u v r B$, katE katG

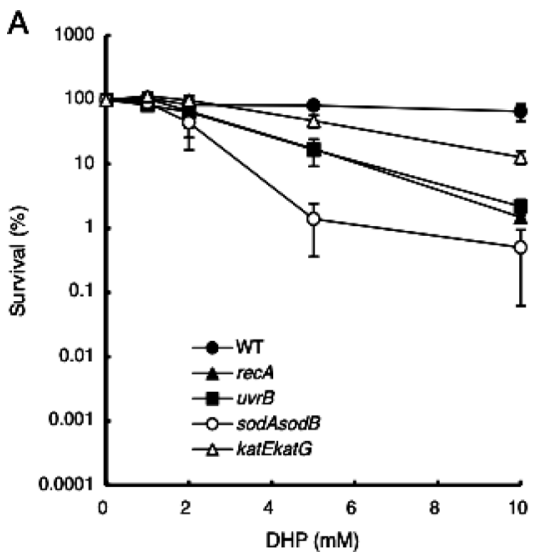

and $\operatorname{sod} A \operatorname{sod} B)$. The $\operatorname{rec} A$ strain is deficient in RecA, a homologous DNA recombination protein. ${ }^{13)}$ The $u v r B$ strain is deficient in UvrB, a nucleotide excision repair protein. ${ }^{14)}$ The katE katG strain is deficient in a monofunctional catalase, hydroperoxidase II (HP II), and a bifunctional catalase-peroxidase, hydroperoxidase I (HPI). ${ }^{15,16)}$ The $\operatorname{sod} A \operatorname{sodB}$ strain is deficient in a manganese superoxide dismutase and an iron superoxide dismutase. ${ }^{17)}$

Figure 3A shows the survival rates of $E$. coli strains undergoing exponential growth after $1 \mathrm{~h}$ of exposure to various concentrations of cyclohexyl-DHP. The wild-type strain exhibited relatively weak sensitivity because $>80 \%$ of the cells survived at cyclohexyl-DHP concentrations below $5 \mathrm{~mm}$ and $66 \%$ survived at a concentration of $10 \mathrm{~mm}$. The $\operatorname{sod} A \operatorname{sodB}$ strain exhibited the highest sensitivity toward cyclohexylDHP because $1.4 \%$ and $0.5 \%$ of the cells survived in the presence of 5 and $10 \mathrm{~mm}$ cyclohexyl-DHP, respectively. The rec $A$ and $u v r B$ strains exhibited the next highest sensitivities toward cyclohexyl-DHP, and the katE katG strain exhibited modest sensitivity. In the presence of $\mathrm{Cu}^{2+}$, enhanced lethal effects of cyclohexyl-DHP resulted in no significant differences among the examined strains. (Fig. 3B).

Increased Mutagenesis in the $\operatorname{sod} A \operatorname{sodB}$ Strain by $\mathrm{Cy}$ clohexyl-DHP Next, we investigated the mutagenicity of cyclohexyl-DHP by evaluating the frequency of rifampicin-

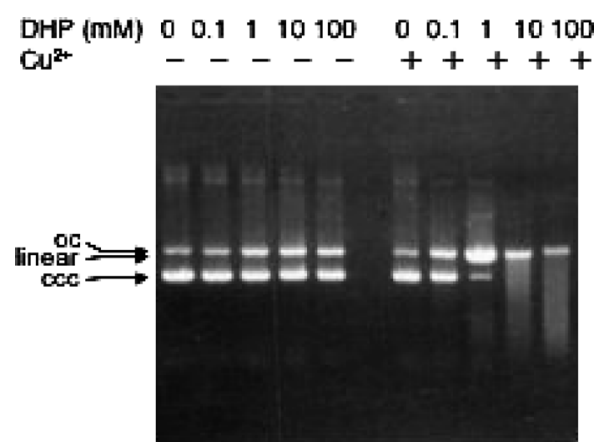

Fig. 2. DNA Strand Breakage by Cyclohexyl-DHP

Reaction mixtures containing $1 \mu \mathrm{g}$ of plasmid pUC18 were incubated with cyclohexyl-DHP in the presence or absence of $1 \mathrm{mM} \mathrm{CuCl} 2$ for $1 \mathrm{~h}$ at $37^{\circ} \mathrm{C}$. The resulting mixtures were analyzed by $0.8 \%$ agarose gel electrophoresis and stained with $0.5 \mu \mathrm{g} / \mathrm{ml}$ ethidium bromide. The plasmid DNA is present in covalently closed circular (CCC), open circular (OC) and linear forms.

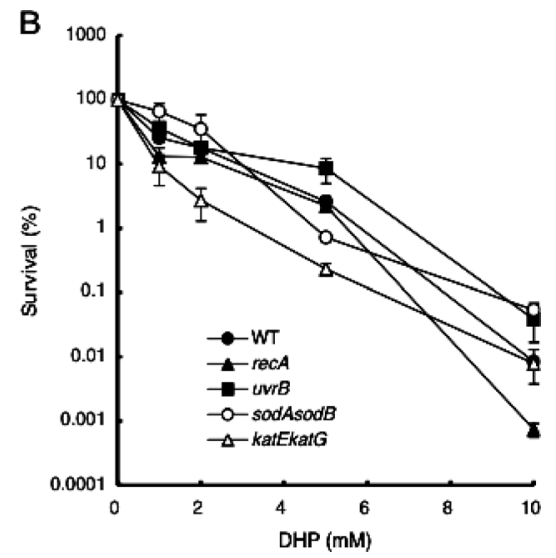

Fig. 3. Survival Rates of E. coli Strains Exposed to Cyclohexyl-DHP

E. coli strains undergoing exponential growth were challenged with various concentrations of cyclohexyl-DHP $(0-100 \mathrm{~mm})$ at $37^{\circ} \mathrm{C}$ for $1 \mathrm{~h}$ in the absence $(\mathrm{A})$ or presence $(\mathrm{B})$ of $1 \mathrm{mM} \mathrm{CuCl}_{2}$. The cells were then diluted in $\mathrm{M} 9$ and plated on LB agar. The data points reflect the average values obtained from at least four independent experiments. 


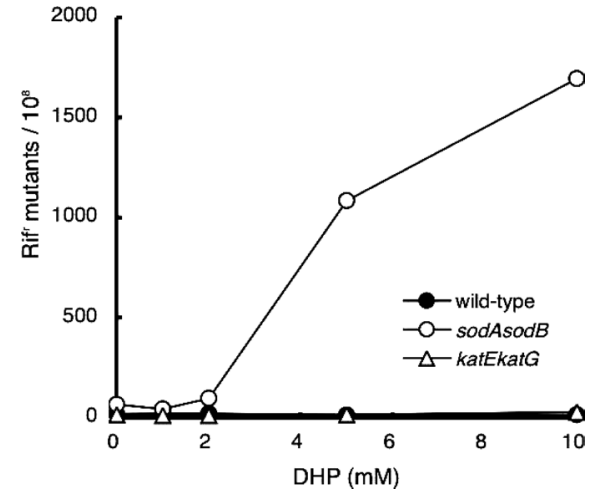

Fig. 4. Mutation Frequencies of E. coli Strains Exposed to CyclohexylDHP

E. coli strains undergoing exponential growth were challenged with various concentrations of cyclohexyl-DHP $(0-10 \mathrm{~mm})$ at $37^{\circ} \mathrm{C}$ for $1 \mathrm{~h}$. The cells were then washed with M9 and plated on LB agar containing rifampicin $(100 \mu \mathrm{g} / \mathrm{ml})$. The data points reflect the average values obtained from at least four independent experiments.

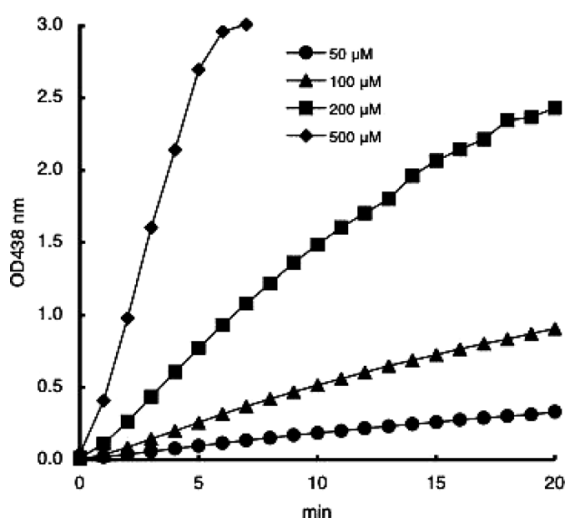

Fig. 5. Generation of Superoxide Anions by Cyclohexyl-DHP

Assay mixtures containing $50 \mathrm{~mm}$ phosphate buffer ( $\mathrm{pH} 7.5), 2 \mathrm{~mm}$ WST-1 and various concentrations of cyclohexyl-DHP $(50-500 \mu \mathrm{M})$ were incubated at room temperature.

sensitive to rifampicin-resistant mutations. The target of rifampicin is the $\beta$ subunit of RNA polymerase, which is a product of the $r p o B$ gene. Rifampicin-resistant mutants predominantly have base-substitution missense mutations in the $r p o B$ gene. ${ }^{18)}$ As shown in Fig. 4, the $\operatorname{sod} A \operatorname{sod} B$ strain exhibited very high frequencies of cyclohexyl-DHP-induced rifampicin-resistant mutants compared with the wild-type strain. The katE katG strain hardly changed the mutation frequencies as well as the wild-type strain.

Superoxide Anion Generation by Cyclohexyl-DHP Since the $\operatorname{sod} A \operatorname{sod} B$ strain was highly sensitive to cyclohexyl-DHP (Figs. 3, 4), we examined the generation of anion radicals by cyclohexyl-DHP using the highly water-soluble tetrazolium salt WST-1. ${ }^{19)}$ As shown in Fig. 5, cyclohexylDHP significantly increased superoxide anion generation in a dose-dependent manner.

Increased Protein Carbonyl Levels in E. coli by Cyclohexyl-DHP Reactive oxygen species cause oxidative modification of proteins, and as a consequence, carbonyl groups are introduced into protein side chains. To examine the protein carbonyl levels in E. coli induced by cyclohexyl-DHP, bacteria exposed to cyclohexyl-DHP were harvested and their total proteins were treated with DNPH. The DNP-derivatized proteins were detected by immunoblotting with an
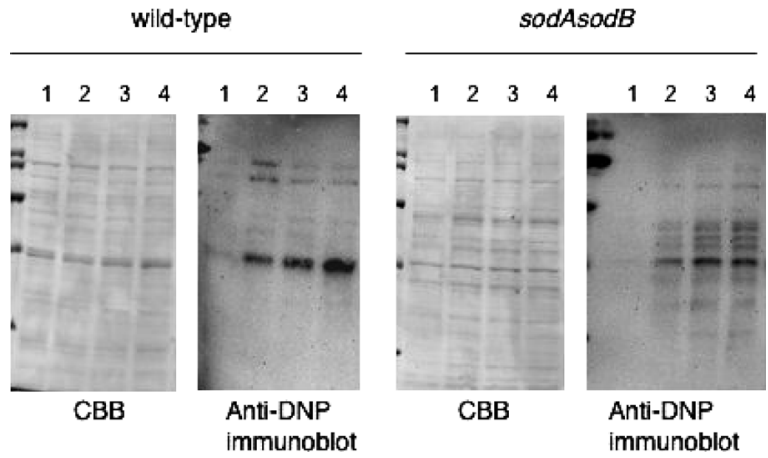

Fig. 6. Protein Carbonyl Levels in E. coli Induced by Cyclohexyl-DHP

$E$. coli strains undergoing exponential growth were challenged with various concentrations of cyclohexyl-DHP at $37^{\circ} \mathrm{C}$ for $1 \mathrm{~h}$. The cells were then harvested and resuspended in $50 \mathrm{~mm}$ potassium phosphate buffer ( $\mathrm{pH} 7.5$ ) containing $2 \%$ 2-mercaptoethanol. DNPH derivatization and immunodetection of DNP-derivatized proteins were carried out using an OxyBlot Protein Oxidation Detection Kit. The resulting mixtures were analyzed by $10 \%$ SDS-PAGE followed by staining with Coomassie Brilliant Blue (CBB) or anti-DNP immunoblot analysis. Lanes 1: absence of cyclohexyl-DHP; lanes 2: $1 \mathrm{~mm}$ cyclohexyl-DHP; lanes 3: $2 \mathrm{~mm}$ cyclohexyl-DHP; lanes 4: $5 \mathrm{~mm}$ cyclohexyl-DHP.

anti-DNP antibody (Fig. 6). Coomassie Brilliant Blue staining showed little difference between the cyclohexyl-DHP-exposed samples and untreated controls. On the other hand, anti-DNP immunostaining revealed that the overall DNP-derivatized proteins were dose-dependently increased in both the wild-type and $\operatorname{sod} A \operatorname{sodB}$ strains by cyclohexyl-DHP. In the wild-type strain, a few DNP-derivatized protein bands were reliably detected, and unexpectedly, the levels of high molecular weight DNP-derivatized proteins were maximal at $1 \mathrm{~mm}$ cyclohexyl-DHP. In contrast, many faint DNP-derivatized protein bands were detected in the $\operatorname{sod} A \operatorname{sod} B$ strain.

\section{DISCUSSION}

In the present study, we investigated the genotoxic and cytotoxic potentials of cyclohexyl-DHP possessing DNA strand-breaking activity. Compared with the wild-type $E$. coli strain, the $\operatorname{sod} A \operatorname{sod} B$ strain showed the highest sensitivity and the rec $A$ and $u v r B$ strains showed the next highest sensitivities to cyclohexyl-DHP. The $\operatorname{sod} A \operatorname{sod} B$ strain also showed an increased mutation frequency. In addition, cyclohexyl-DHP strongly induced superoxide anion generation and increased the protein carbonyl levels in E. coli. These findings indicate that cyclohexyl-DHP could potentially generate free radicals, including superoxide anions, and not only cause breakage of chromosomal DNA leading to mutagenic lesions but also induce oxidative damage to cellular proteins.

We recently reported the properties of some DHP derivatives that have the bactericidal activities. The rec $A$ and $u v r B$ strains were highly sensitive to Me-DHPs ${ }^{20,21)}$ and weakly sensitive to Ph-DHPs. ${ }^{8)}$ In addition, the $u v r B$ strain showed an increased mutation frequency. ${ }^{20,22)}$ By contrast, the $\operatorname{sod} A$ $\operatorname{sodB}$ strain was highly sensitive to $\mathrm{Ph}-\mathrm{DHPs}^{8)}$ and weakly sensitive to Me-DHPs. ${ }^{20,21)}$ Thus, Me-DHPs exert genotoxic effects while Ph-DHPs exert cytotoxic effects. Addition of $\mathrm{Cu}^{2+}$, which is expected to promote a Fenton-type reaction, ${ }^{23)}$ enhanced both the DNA strand-breaking and bactericidal activities of DHPs. The productions of various radical species, i.e., hydroxyl, superoxide and carbon-centered radicals, were detected in the ESR spectrum. ${ }^{7,21)}$ Upon addition of $\mathrm{Cu}^{2+}$, the 
signal intensities of the hydroxyl radicals generated by MeDHP, Ph-DHP and cyclohexyl-DHP increased by about 8-, 16- and 60-fold, respectively, in the ESR spectrum (unpublished data).

Taking these previous reports and our unpublished data together, in the absence of $\mathrm{Cu}^{2+}$, the $\operatorname{sod} A \operatorname{sod} B$ strain is highly sensitive to Ph-DHPs and cyclohexyl-DHP, whereas the rec $A$ and $u v r B$ strains are relatively insensitive to these compounds. These findings suggest that, in contrast to Me-DHPs, the toxicity of Ph-DHPs and cyclohexyl-DHP may preferentially cause damage to subcellular components rather than chromosomal DNA. In the presence of $\mathrm{Cu}^{2+}$, the production of hydroxyl radicals and hydrogen peroxide could be enormously increased by the Fenton-type reaction, such that the bactericidal activity of DHP would become maximal toward all the tested strains.

Oxygen radicals, including superoxide anions, are generated not only by environmental factors, such as ionizing radiation and chemicals, but also during cellular metabolic processes, such as mitochondrial electron transport, immune responses and the cellular redox system. ${ }^{24,25)}$ Despite the presence of various antioxidant defenses to protect against radicals, ${ }^{25)}$ radicals can damage subcellular components, thereby resulting in apoptosis, cancer, neurodegenerative diseases, chronic inflammatory diseases, cardiovascular diseases and aging. ${ }^{26-28)}$

Our present study provides evidence that DHP, as a glycation intermediate, can generate oxygen radicals, resulting in the induction of mutagenesis and protein oxidation. On the basis of these observations, we propose that DHP could play a role in carcinogenesis.

Acknowledgments We are grateful to Dr. H. Niki (NIG, Japan) for supplying the bacterial strains.

\section{REFERENCES}

1) Kashige N., Yamaguchi T., Mishiro N., Hanazono H., Miake F.,
Watanabe K., Biol. Pharm. Bull., 18, 653-658 (1995).

2) Yamaguchi T., Matsumoto S., Watanabe K., Tetrahedron Lett., 39, 8311 -8312 (1998).

3) Maga J. A., Sizer C. E., J. Agric. Food Chem., 21, 22-30 (1973).

4) Zlatkis A., Bertsch W., Lichtenstein H. A., Tishbee A., Shunbo F., Liebich H. M., Coscia A. M., Fleischer N., Anal. Chem., 45, 763-767 (1973).

5) Takechi S., Yamaguchi T., Nomura H., Minematsu T., Nakayama T., Mutat. Res., 560, 49-55 (2004).

6) Yamaguchi T., Eto M., Harano K., Kashige N., Watanabe K., Ito S., Tetrahedron, 55, 675-686 (1999).

7) Kashige N., Takeuchi T., Matsumoto S., Takechi S., Miake F., Yamaguchi T., Biol. Pharm. Bull., 28, 419-423 (2005).

8) Takeda O., Takechi S., Ito S., Omori H., Katoh T., Yamaguchi T., Biol. Pharm. Bull., 30, 1663-1667 (2007).

9) Maruoka H., Kashige N., Miake F., Yamaguchi T., Chem. Pharm. Bull., 53, 1359-1361 (2005).

10) Yamaguchi T., Ito S., Kashige N., Nakahara K., Harano K., Chem. Pharm. Bull., 55, 532-36 (2007).

11) Howard-Flanders P., Boyce R. P., Theriot L., Genetics, 53, 11191136 (1966).

12) Howard-Flanders P., Theriot L., Genetics, 53, 1137-1150 (1966).

13) Clark A. J., Margulies A. D., Proc. Natl. Acad. Sci. U.S.A., 53, 451459 (1965)

14) Theis K., Skorvaga M., Machius M., Nakagawa N., Van Houten B., Kisker C., Mutat. Res., 460, 277-300 (2000).

15) Loewen P. C., J. Bacteriol., 157, 622-626 (1984).

16) Loewen P. C., Triggs B. L., George C. S., Hrabarchuk B. E., J. Bacteriol., 162, 661-667 (1985).

17) Carlioz A., Touati D., EMBO J., 5, 623-630 (1986).

18) Jin D. J., Zhou Y. N., Methods Enzymol., 273, 300-319 (1996).

19) Ukeda H., Shimamura T., Tsubouchi M., Harada Y., Nakai Y., Sawamura M., Anal. Sci., 18, 1151-1154 (2002).

20) Takechi S., Yamaguchi T., Nomura H., Minematsu T., Nakayama T., Mutat. Res., 560, 49-55 (2004).

21) Takeda O., Takechi S., Katoh T., Yamaguchi T., Biol. Pharm. Bull., 28, 1161-1164 (2005).

22) Takechi S., Yamaguchi T., Nomura H., Minematsu T., Adachi M., Kurata H., Kurata R., Biol. Pharm. Bull., 29, 17-20 (2006).

23) Imlay J. A., Chin S. M., Linn S., Science, 240, 640-642 (1988).

24) Cance B., Sies H., Boveris A., Physiol. Rev., 59, 527-605 (1979).

25) Weizman S. A., Gordon L. I., Blood, 76, 655-663 (1990).

26) Halliwell B., Lancet, 344, 721—724 (1994).

27) Halliwell B., Gutteridge J. M., Methods Enzymol., 186, 1—85 (1990).

28) Stadtman E. R., Science, 257, 1220-1224 (1992). 